\title{
Pronunciation of Grade IV Students in Reading Poetry at SDN Bontokamase Gowa
}

\author{
Mansyur Suma \\ Bahasa Indonesia Faculty, Universitas Islam Negeri Alauddin, Makassar. 90222, South Sulawesi, Indonesia
}

Received August 17, 2020; Revised March 5, 2021; Accepted April 26, 2021

\section{Cite This Paper in the following Citation Styles}

(a): [1] Mansyur Suma, "Pronunciation of Grade IV Students in Reading Poetry at SDN Bontokamase Gowa," Universal Journal of Educational Research, Vol. 9, No. 5, pp. 1014 - 1024, 2021. DOI: 10.13189/ujer.2021.090514.

(b): Mansyur Suma (2021). Pronunciation of Grade IV Students in Reading Poetry at SDN Bontokamase Gowa. Universal Journal of Educational Research, 9(5), 1014 - 1024. DOI: 10.13189/ujer.2021.090514.

Copyright $\bigcirc 2021$ by authors, all rights reserved. Authors agree that this article remains permanently open access under the terms of the Creative Commons Attribution License 4.0 International License

\begin{abstract}
This study aims at describing the pronunciation of fourth grade students in reading poetry at SDN Bontokamase Gowa. The study was a quantitative descriptive study. The population was the students in all elementary schools in Gowa district. The sample of the study was all students in grade IV at SDN Bontokamase Gowa that consisted of 20 females and 17 males. The data of the study were collected through observation, documentation, and field note. The data were analyzed by using quantitative descriptive analysis to understand the pronunciation of fourth grade students in reading poetry. The results of the study showed that there were 27 students with high score, 7 students with medium score and 3 students with low score assessed by three assessors. The students with very good score can pronounce well with accurate word and clear in reading title, lines and rhymes. While the three students with low score cannot pronounce with accurate word and clear in reading title, lines and rhymes. While the average score of students' pronunciation is 3. 49. Thus, it was concluded that the skills to read poetry of students in terms of pronunciation aspect were in a very good category.
\end{abstract}

Keywords Pronunciation, Reading, Poetry, Students

\section{Introduction}

Literature is essentially not only to be taught, but also to understand the use of the literature itself. Students with literary knowledge can understand the benefits of literature, especially poetry. For this reason, poetry can be positioned as a literary work and there is a connection between life and the learning process takes place. Thus, literature becomes part of a science unconsciously. The knowledge will benefit life especially as a student.

According to (Doyin, 2010), poetry is actually expression of writer's feelings or thoughts. Whatever a writer expresses in poetry is what he or she thinks or feels to respond something. Thus, the writer can convey the implied meaning in his or her poetry to the reader. The poetry itself is to keep the writer's impressive experience and it has a certain sense or value.

(Wei, 2010) also defined poetry as a shout or laugh deep inside of heart, a song that is sung inside soul, a picture from imagination, and words with style. Poetry is art that consists of reality, philosophy, ideology. Poetry comes from feelings and emotion. Thus, poetry is representative of feelings in words and rhythm.

Teaching poetry does not only begin with literature itself, but also with the persons who will learn it. The environment, background and needs of those who want to be given literary lessons (thematic) should not be less important than the other works. Literary learning starts from real actions. Literary works (poetry) do not silence the readers, but instead offer the readers to develop its interpretation; it also becomes the inspiration and imagination for the next works.

The researcher concludes that students cannot be separated from language competence and appreciation of poetry. In this case, the appreciation of poetry is about how the students can appreciate, understand, evaluate, and produce poetry as a good literary work. Achievement of learning outcomes or the appreciation itself is certainly supported by the implementation of the learning process. 
Implementation of learning in class is conducted with a variety of approaches, methods, strategies which are innovative, creative, and interesting, thus the achievement of learning outcomes can be maximized and meaningful. One method that would be developed is thematic learning.

This study is based on the idea that in order to improve students' skills to read poetry, a technique that prioritizes the ability to imagine is needed by exercising the skills to concentrate and think through the students' suggestions. The students' reading skills are based on the ability to express ideas, thoughts, and feelings through the elements of language, thus what you want to convey to the listener can be achieved.

Poetry reading learning can be used as an effort to achieve goals to understand reading poetry listed in the curriculum. The aim of literary learning is that students can enjoy and utilize literary works to broaden their horizons, refine their character, and improve their knowledge and language skills, thus students are able to appreciate and develop Indonesian literature as a cultural and intellectual property of humans.

Based on the contents of the standard in the National Education Standards (SNP), curriculum development of Indonesian language and literature teaching contains aspects of the skills that must be mastered, namely aspects of listening, speaking, reading, and writing skills. These four skills are related to each other. One aspect of language that will be developed as language teaching is directed to help students get to know themselves, culture, express ideas or feelings, and participate in society. In addition, language learning helps the students to use the analytical and imaginative skills of the poetry. Therefore, students are expected to be able to communicate in Indonesian properly and correctly.

The ability to read poetry, especially for students of grade IV at SDN Bontokamase is in accordance with the results of the conversation between the researcher and the teacher in grade IV that poetry learning is only taught on an integrated thematic basis. They have not been taught about: What is the ability to read poetry of students at SDN Bontokamase Gowa in pronouncing an array of words, phrases, and sentences in a poetry. The thematic curriculum for class IV at SDN Bontokamase contains learning poems that are short and simple. (Wilson, 1985) states that in choosing poetry there are several things that need to be considered namely the pronunciation, intonation, gestures and expressions.

There are several problems faced by students in appreciating poetry. The most common problem felt by students is to choose diction that is poetic and dense of meaning. In general, students have difficulty in reading poetry including pronunciation, intonation, gesture, and appreciation. While, the teacher still uses conventional methods such as assignments, discussions, demonstrations, and also questions and answers. It can be concluded that the low ability to read poetry is caused by the lack of interesting ways of learning poetry. In order to overcome the problem, it is important to conduct a research about poetry reading skills that starts from pronunciation, intonation, gestures, expressions, and visions.

Besides meaning of poetry, pronunciation is also important element to be assessed in reading poetry. If we only pay attention to the meaning of a poem, we only reduce it to a piece of unrelated cords (without meaning). The correct answer begins by noting that the elements (signs) in a poem often seem to deviate from normal grammar or normal description (Tang, 2008). Thus, the researcher intended to conduct study about poetry reading skills of the fourth grade students in case of pronunciation.

The difference between the previous study and this study is seen in subject, object and the method of the study. The researcher examined the poetry reading skills by assessing the pronunciation during reading poetry. The researcher also applied the model proposed by Wilson that may overcome problems faced by students in reading poetry. The reading model was based on four skills, namely pronunciation, intonation, gestures, expression and appreciation.

\section{Review of Related Literature}

\subsection{The Concept of Reading}

Reading is one aspect of language skills that are complex and complicated. According to (Soedarso, 1991), reading is a complex activity by mobilizing a large number of separate actions. (Adler and Doren, 2007) also suggest that "reading is a complex activity, just like writing. He stood up and had many separate mental actions, and all had to be done in order to read well ". (Farida, 2009) states that reading is essentially a complicated thing that involves many things, not just reciting writing, but also involves visual, thinking, psycholinguistic, and meta-cognitive activities ". This is in line with the opinion of (Prasetyono, 2008) that reading is a series of mind activities carried out attentively to understand information through the sense of sight in the form of complex symbols, arranged so that they have meaning and meaning. "

Godman in (Somadayo, 2011) also states that "reading is an activity of picking meaning or understanding that is not only from the rows of explicit words (reading the lines), but the meaning behind the rows contained between lines (reading between the lines), even the meaning that lies behind these lines (reading beyond the lines) ". Reading activity is not a passive process, but it is an active process which means that a reader must actively try to understand the contents of a reading. (Nurgiyantoro, 2010) argues that "reading is a mental activity to understand what is said by other parties through the means of writing". Reading activity is a mental activity to understand what is said by the other party through the means of writing". 
(Nugriyantoro, 2010) also adds that "reading activities are an effort to understand information conveyed through written symbols". Reading activities are very important in daily life, especially in language learning at school. Students are not only required to be able to read, but also to know and understand the meaning of the information contained in the reading. Hodgson, 1960 in (Tarigan, 2008), argues that "reading is a process carried out and used by readers to obtain messages, which will be conveyed by the author through the media words / writings". From some of the opinions above, it was concluded that reading is a complex behavior carried out to define written symbols so that they can know their meaning.

\subsection{The Concept of Poetry Reading}

According to (Doyin, 2010), reading in the concept of poetry reading must be understood as an effort to understand and feel everything contained in a poem. With these activities, intended is felt by the poet writer controlled by the reader. So, poetry reading is not just speaking poetry or voicing poetry, but also expressing the feelings and souls captured by the reader of the poem.

According Suharianto in (Doyin, 2010), the art of poetry reading is essentially the art of spectacle. The art of poetry reading is audiovisual art. As an audiovisual art, the art of poetry reading is required to be pleasing to the ear and pleasing to the eye. In order to be pleasant to hear, everything produced by the reader's utensils must be true and beautiful. In order to be pleasing to the eye, all the movements produced by the poet's body must also be true and beautiful. Therefore, poetry reading belongs to the performing arts.

If language skills include four aspects, namely listening, speaking, reading, and writing, poetry reading is included in the reading category. (Istanti, 2009), also reveals the notion of poetry reading: poetry reading is understanding the meaning contained in poetry and capturing the thoughts and feelings of the poet so that it can be enjoyed by the audience.

According to (Doyin, 2010), it also states that, there are three components of reading, namely vocals, appreciation, and appearance in the art of poetry reading, namely: vocals, appreciation, and appearance.

Vowels are not just volume or loudness of sound. Sometimes there is a misunderstanding that, who has a loud, determined, and demonstrative voice who is certainly beautiful and wins the race. Matters related to vocals are articulation (pronunciation correctness), tempo (speed of reading), tone (high and low reading), and accentuation (emphasis).

There are at least four main concerns in the vocal issue, namely: (1) clarity of speech; (2) pause; (3) resilience; and (4) fluency (Doyin, 2010). Every word in a poem must be clearly heard by the listener or audience. At least this is the main criterion of a poet's vocal reader. A person's voice color problem is not directly related to speech clarity. The color of the sound is heavy, high, large, or small, all of which can produce a clear sound if the owner is diligently conducting exercises.

(Doyin, 2010) argues that appreciating poetry means understanding the whole contents of poetry. The contents are essential things in poetry because it may have implied meaning. Understanding of poetry that is categorized in this appreciation does not merely understand the meaning of words or lines of poetry, but comes to an understanding of the meaning contained in poetry and the atmosphere of the poem itself. The understanding of poetry must be done by poetry readers. Poetry reading is an effort to help the listener or audience understands the contents of the poem.

Before we help the listener understand the contents of the poem, we must first understand it. At least in this step we must be able to capture the meaning contained in the poem, the meaning of the symbols contained in the poem, and the atmosphere. The appreciation in the art of poetry reading is at least reflected in three things, namely: (1) beheading; (2) tone and intonation; and (3) expression.

According to (Doyin, 2010), appearance problems in reading poetry concern issues: (1) techniques emerge; (2) block and use settings; (3) reading techniques; and (4) how to dress. The first thing to note in a poetry reading performance is the emergent technique. Emerging technique is the way taken by poetry readers in showing themselves for the first time. A good and solid impression must be displayed in the first appearance. This is important because success in the first appearance will have a major effect on the success of subsequent readings.

Pronunciation is a basic part of voice arrangements (Salad, 2014). He explained that without pronunciation, voice arrangement is not meaningful for the listener. Pronunciation is defined as ways to pronounce words and phrases with a clear voice and appropriate with phonological. The clearness of pronunciation in reading poetry is very important. Vowels of /a/, /i/, /u/, /e/, /o/, /ai/, /au/ and the others should be listened clearly, similarly the consonants.

\subsection{Related Studies}

(Yanti, 2018) conducted study to see the poetry reading skills of the students of SMPN 5 Kuantan Mudik in pronunciation, stressing the words, intonation and expression. The results of the study showed that the average of poetry reading skills of students grade VII of SMPN 5 Kuantan Mudik in pronunciation was $78.21 \%$ or in a good category. In stressing the words, it was found that the average of poetry reading skills of students grade VII of SMPN 5 Kuantan Mudik was 96\% or categorized as good. The average poetry reading skills of students grade VII of SMPN 5 Kuantan Mudik in intonation was $78.85 \%$ or good. The average of poetry reading skills of 
students grade VII of SMPN 5 Kuantan Mudik on the expression was $67.85 \%$ or sufficient.

(Wahyuningsih, 2015) conducted study to find out the poetry reading skills of the first-year students of Al-Uswah Pekanbaru vocal precision, intonation, and appreciation (expression). The results of this study showed that the reading skills to read poetry in aspects of vocal accuracy category were 60.99 or $76.24 \%$. The poetry reading skills in intonation aspect being categorized were 47.26 or $78,77 \%$. The poetry reading skills in the aspect of appreciation (expression) were in low category with a mean of 41.22 or $68.71 \%$. Overall, it can be concluded that the ability of the first year students of Al-Uswah Pekanbaru. In reading poetry is categorized with average 143.59 (for two poems) or $71.80 \%$.

(Surastina, 2016) conducted study to describe the students common errors in reading a famous Indonesian poetry entitled Aku by Chairil Anwar. This study was conducted to 120 primary students in Lampung Province, Indonesia which has been randomly chosen by using stratified random sampling technique. The result showed that most of students have low skills in reading poetry as indicated by high percentage of students doing errors. Error in articulating was mainly caused by different student dialect, meanwhile error in stressing intonation was affected by low ability in interpreting poetry and their tendency in reading with specific pattern. This finding can be used as a reference to evaluate student skills in reading Indonesian poetry.

(Sudiar et al, 2014) conducted study to increase the ability in reading poem of students grade five of SDN18 Matan Hilir Selatan Kabupaten Ketapang. The method used in this study is modeling. Basically the study was designed in an action called a cycle. While the nature of this research is Classroom Action Research (CAR). The results showed an increase in the ability to read poetry on aspects of pronunciation, intonation, and expression. In the process of learning Indonesian, the aspects of pronunciation have increased from an average pre-cycle 20.00 , the first cycle of 21.92 on average an increase of 1.92 , in the second cycle of 23.86 on average an increase of 1.94. In intonation aspects, the pre-cycle increased average 20.00 , the first cycle of 20.77 on average an increase of 0.77 , in the second cycle of 23.08 on average an increase of 2.31. In expression aspects, the pre-cycle was 16.92 , the first cycle of 23.85 on average an increase of 6.93 , in the second cycle on average 30.00 on average an increase of 6.15. In general, concluded that the use of modeling to improve the ability to read poetry in learning Indonesian language support of aspects of pronunciation, intonation, and expression in class $\mathrm{V}$.

Based on the previous study above, the researcher wants to take a different research to describe elementary students' pronunciation in reading Indonesian poetry. In this study, the researcher intended to see the clearness of students' pronunciation in title, lines and rhymes of poetry.

\section{Materials and Methods}

This type of research is quantitative descriptive, using statistics and not generalization; the researcher only wants to see the ability to read poetry of each student. The assessor gives a number, and from that number, the researcher describes it in words. Quantitative research methods can be interpreted as research methods based on the philosophy of post-positivism to examine natural conditions of objects, because the researcher acts as a key instrument (Sugiyono, 2015)

This descriptive quantitative research focuses on the variable of poetry reading ability of the fourth grade students of SD Negeri Bontokamase Sungguminasa, Gowa Regency. In this study, variables are defined as everything that will be the object of research observation. In general, variables are objects that will be used as both abstract and real research. The implementation of this activity must be systematic and in accordance with scientific principles. So, the results of observation can be justified. The theoretical basis used also affects the results obtained. The number of variables is not determined, but depends on the type of research to be conducted.

So, the focus of the research is basically anything in the form of whatever is determined by the researcher to be studied in this study so that information is obtained about it, then conclusions are drawn. The variable in this study is the ability of students to read poetry.

This study uses descriptive quantitative method because it describes the ability to read poetry of fourth grade students of SD Negeri Bontokamase Gowa in pronunciation naturally as it is. It is in line with (Sukmadinata, 2011), that quantitative descriptive research is intended to describe the existing phenomena, both natural and human engineering, which pay more attention to the characteristics, quality, and interrelationships among the activities. In addition, descriptive research does not provide treatment, manipulation or alteration of the variables under study, but rather describes a condition as it is. The only treatment given is the research itself, which is done through observation, interviews, and documentation and tests.

Based on the views of these experts, it can be concluded that quantitative descriptive research is a series of activities to obtain data that is as it is without being in certain conditions whose results emphasize more meaning. Here, the researcher uses a descriptive quantitative research method because this research explores the phenomenon of the ability to read poetry of fourth grade students of SD Negeri Bontokamase Gowa.

The population in this study was all elementary school students in Gowa District. Furthermore, the sample was 20 female students and 17 male students in this study who were fourth grade students of SD Negeri Bontokamase Gowa. The data in this study are the students' value in reading poetry, which is seen from the aspect of pronunciation. While the source of the data is in the research is the fourth grade students of SD Negeri 
Bontokamase in Gowa Regency, the fourth grade students are 37 people, consisting of 20 female students and 17 male students. This research was conducted in class IV SD Negeri Bontokamase Gowa as one of the leading schools in Gowa District. Because this research is expected to be one of the models of teaching Indonesian Language in Elementary Schools of Gowa district, the selection of superior schools as places to conduct research is one of the fundamental reasons. Another consideration is the ease of outreach in conducting research.

Data collection is done by using observation techniques, video recording, and photos during poetry reading takes place. The observation is that the writer makes direct observations of poetry readings by Grade IV students of SD Negeri Bontokamase Gowa by using an audiovisual recording device in the form of video. The data analysis technique of the research results is done in two ways.

The first, the researcher adds the value of the respondent abbreviated with $\mathrm{R}$ based on the results of the assessment instruments used then divided by the number of respondents guided by the following table with the following formula:

$$
M e=\frac{\sum x i}{n}
$$

Where:

$\mathrm{Me}=$ Mean (average)

$\mathrm{Xi}=$ value $\mathrm{X}$ to $\mathrm{I}$ get to $\mathrm{n}$

$\mathrm{n}=$ Number of individuals

The second, the students' pronunciation would be described based on the criteria of Departemen Pendidikan Nasional (2006).

\section{Results}

The data of this study are the ability to read poetry in the fourth grade students of SD Negeri Bontokamase Gowa, amounting to 37 people with details of 20 females, 17 males. The results of research on students' ability to read poetry can be presented as follows:

\section{The Value of Reading Poetry Based on the Pronunciation}

Table 1. Frequency and percentage categories of Reading Poetry Based on the Pronunciation

\begin{tabular}{ccc}
\hline Category & Frequency & Percentage \\
High $(81-100)$ & 27 & $73 \%$ \\
Medium $(61-80)$ & 7 & $19 \%$ \\
Low $(40-60)$ & 3 & $8 \%$ \\
Total & 37 & $100 \%$ \\
\hline
\end{tabular}

Based on the table 1, there are 27 students who received the category of High with a score range of 81-100. The indicators of high score were the students who can pronounce the phoneme of the title of the poem and array accurately and very clearly. There were 27 or $73 \%$ of the students who can pronounce title and lines accurately and clearly.

While, there were 7 or $19 \%$ of all students who were in the Medium category with a score range of 61-80. The indicators of medium score are how students can pronounce the phoneme of the title and lines accurately but unclearly.

There are 3 or $8 \%$ of all students who get Low category with a range of scores 40-60. The indicators of low category were the students who can pronounce phonemes and consonants of poetry titles and lines are very unclear. 
Table 2. The Value of Reading Poetry Based on the Pronunciation by three assessors

\begin{tabular}{|c|c|c|c|c|c|c|}
\hline \multicolumn{7}{|c|}{ Pronunciation aspect } \\
\hline \multirow[b]{2}{*}{ Respondents } & \multicolumn{3}{|c|}{ Assessor } & \multirow[b]{2}{*}{ Mean Score } & \multirow[b]{2}{*}{$\%$} & \multirow[b]{2}{*}{ Category } \\
\hline & $\mathbf{I}$ & II & III & & & \\
\hline $\mathrm{R} 1$ & 4 & 4 & 3 & 3.67 & 91,67 & Very Good \\
\hline $\mathrm{R} 2$ & 3 & 4 & 3 & 3.33 & 83,33 & Very Good \\
\hline R3 & 4 & 4 & 4 & 4.00 & 100 & Very Good \\
\hline $\mathrm{R} 4$ & 3 & 4 & 4 & 3.67 & 91,67 & Very Good \\
\hline R5 & 4 & 4 & 2 & 3.33 & 83.33 & Very Good \\
\hline R6 & 4 & 4 & 4 & 4.00 & 100 & Very Good \\
\hline R7 & 4 & 4 & 4 & 4.00 & 100 & Very Good \\
\hline $\mathrm{R} 8$ & 4 & 4 & 2 & 3.33 & 83.33 & Very Good \\
\hline R9 & 3 & 4 & 2 & 3.00 & 75.00 & Good \\
\hline $\mathrm{R} 10$ & 4 & 4 & 2 & 3.33 & 83.33 & Very Good \\
\hline R11 & 3 & 4 & 3 & 3.33 & 83.33 & Very Good \\
\hline $\mathrm{R} 12$ & 3 & 3 & 3 & 3.00 & 75.00 & Good \\
\hline R13 & 4 & 4 & 4 & 4.00 & 100 & Very Good \\
\hline R14 & 4 & 3 & 4 & 3.67 & 91.67 & Very Good \\
\hline R15 & 3 & 3 & 4 & 3.33 & 83.33 & Very Good \\
\hline R16 & 4 & 3 & 3 & 3.33 & 83.33 & Very Good \\
\hline $\mathrm{R} 17$ & 4 & 4 & 4 & 4.00 & 100 & Very Good \\
\hline R18 & 3 & 3 & 4 & 3.33 & 83.33 & Very Good \\
\hline R19 & 3 & 2 & 3 & 2.67 & 66.67 & Adequate \\
\hline $\mathrm{R} 20$ & 4 & 4 & 4 & 4.00 & 100 & Very Good \\
\hline R21 & 3 & 3 & 3 & 3.00 & 75.00 & Good \\
\hline R22 & 4 & 3 & 3 & 3.33 & 83.33 & Very Good \\
\hline $\mathrm{R} 23$ & 3 & 2 & 3 & 2.67 & 66.67 & Adequate \\
\hline R24 & 4 & 4 & 3 & 3.67 & 91.67 & Very Good \\
\hline R25 & 2 & 2 & 3 & 2.33 & 58.33 & $\mathrm{Bad}$ \\
\hline R26 & 3 & 4 & 4 & 3.67 & 91.67 & Very Good \\
\hline R27 & 4 & 3 & 4 & 3.67 & 91.67 & Very Good \\
\hline R28 & 4 & 2 & 3 & 3.00 & 75.00 & Good \\
\hline R29 & 4 & 4 & 4 & 4.00 & 100 & Very Good \\
\hline R30 & 4 & 4 & 4 & 4.00 & 100 & Very Good \\
\hline R31 & 3 & 4 & 3 & 3.33 & 83.33 & Very Good \\
\hline R32 & 4 & 4 & 4 & 4.00 & 100 & Very Good \\
\hline R33 & 4 & 3 & 4 & 3.67 & 91.67 & Very Good \\
\hline R34 & 4 & 3 & 4 & 3.67 & 91.67 & Very Good \\
\hline R35 & 4 & 3 & 4 & 3.67 & 91.67 & Very Good \\
\hline R36 & 3 & 3 & 3 & 3.00 & 75.00 & Good \\
\hline R37 & 4 & 4 & 4 & 4.00 & 100 & Very Good \\
\hline Total & 133 & 128 & 126 & 3.49 & 87.16 & Very Good \\
\hline Average & 3.59 & 3.46 & 3.40 & & & \\
\hline$\%$ & 89.86 & 86.49 & 85.14 & & & \\
\hline
\end{tabular}


Table 2 showed that in the first assessment, the average ability of students in reading poetry from the pronunciation aspect is in the very good category with a percentage of $89.86 \%$. At the pronunciation stage, students are able to recite poetry very well. Every student who is given the number 4 can mention each word well without the slightest mistake. In the second assessment, the average ability of students reading poetry from the pronunciation aspect is in the very good category with a percentage of $86.49 \%$. In the third assessment, the ability of students to read poetry from the pronunciation aspect is in very good category with a percentage of $85.14 \%$. When viewed from all assessors, the average ability of students reading poetry from the pronunciation aspect is in the very good category with a percentage of $87.16 \%$.

The average score above showed that the students can pronounce the words in the poetry very well. For example, Respondent 2 (R2) is able to pronounce the words of "syukur," not "sukur" on the array of "yang membuat kita bersyukur pada Ilahi" in Hidup Penuh Warna poetry. The respondent is able to pronounce the word even though it is derived from Arabic (loanword). Another loanword from Arabic that can be pronounced correctly is the word of "nasihat" in the Guru Tercinta poem by Respondents 27 and 29 (R27 and R29). In fact, in daily conversation this word is always pronounced with the pronunciation of "nasehat."

\section{Discussion}

Based on previous exposure, it can be stated matters related to several research findings. The meaning of the results of the assessment of the three evaluators on the appearance of grade IV elementary school students in reading poetry is based on pronunciation aspect. Of course the assessor at the time of the assessment has considered many things related to poetry reading activities, although it is undeniable that the emotional involvement and feelings of the assessor is very likely to influence the assessment.

The average score above showed that the students can pronounce the words in the poetry very well. For example, Respondent 2 (R2) is able to pronounce the words of "syukur," not "sukur" on the array of "yang membuat kita bersyukur pada Ilahi" in Hidup Penuh Warna poetry. The respondent is able to pronounce the word even though it is derived from Arabic (loanword). Another loanword from Arabic that can be pronounced correctly is the word of "nasihat" in the Guru Tercinta poem by Respondents 27 and 29 (R27 and R29). In fact, in daily conversation this word is always pronounced with the pronunciation of "nasehat."

The pronunciation of loanwords above showed that articulation is an important thing in reading especially in reading poetry. It is in line with Salad $(2014: 158)$ that articulation is a basic part of voice arrangement (vocal). Wrong articulation will lead students to create mispronunciation.

It is well known that the condition of knowledge and maturity of grade IV elementary school students is not as mature as adults, but reading poetry is not only dependent on the condition of one's knowledge and maturity. Reading poetry is a skill that involves knowledge. Meanwhile, poetry for these students is something that has often been heard and often even read. Whether it's because something has to be learned as part of a competency that must be mastered in certain subjects, or because it has been watched and listened to other people read poetry maybe even he himself has done it. Therefore, it is not surprising that children in grade IV elementary school students are able to read poetry as adults do by paying attention to all aspects of reading poetry.

The respondents 17 and 18 (R17 and R18) who are able to pronounce the word of "riuh" in a poem entitled Penari. The word "riuh" is seldom used in daily conversation and some students never heard the word. However, "riuh" is categorized as a good word to use in Indonesian poetry to create a good rhyme.

From the example above, the researcher found that articulation can be correct if the reader can treat the poetry well. In this case, the reader also focuses on the right articulation thus the poetry becomes more beautiful to be heard. It is in line with (Mulyana.et al, 2008) that the right articulation (correct pronounce) can create a beautiful poetry.

In general, poetry is one of the activities of reading aloud. Reading aloud is essentially the activity of reading by voicing written symbols (letters, syllables, words / phrases, sentences) by paying attention to aspects of the ability to read aloud (pronunciations, intonations, pauses, punctuation marks) so that the listener and reader can capture information and understand the meaning contained in a reading. Therefore, the pronunciation becomes very important to note in reading poetry.

The pronunciation model is a way for a person or group of people to pronounce the sounds of language. The language sounds referred to in Indonesian include Vowels, Consonants, Diphthongs, and Consonants Combined. In the ethics of reading poetry, the pronunciation of language sounds must be clear. Consonants and vowels in each word and sentence must be correct to avoid the emergence of different interpretations and meanings by those who listen to the poetry read. For example the word "simpan" with "simpang" are two words that have different meanings. When reading the two words with unclear pronunciations, it is difficult for the listener to understand the meaning. It could even be considered the word mentioned is irrelevant to the words or sentences that preceded it or those that followed it in the series of sentences.

There were also 3 students who got low score, R19 and 
R23 who got 2 for their poetry reading assessed by the second assessor. The assessor gave 2 for the reading because of unclear pronunciation in title, lines and rhymes. While R25 who get 2 for the first and the second assessor because the pronunciation is not clear and there is mispronunciation in loanword like "nasihat" becomes "nasehat." This mispronunciation happens because the word "nasehat." is usually used in daily conversation, thus the reader cannot detect the word as the wrong word. Other mistakes are from the voice that is not clear, thus the listener cannot listen the whole contents perfectly.

Based on the explanation above, it is concluded that vocal and voice qualities are important things to be assessed in reading poetry. A clear voice and accurate vocal will give the best performance in reading poetry. It is in line with the statement of (Salad, 2014) that pronunciation is a form of expression that can be listened by ears and the variables are on vocal and voice quality.

It is important to realize that reading activities at the elementary school level are part of the elementary curriculum. For example in the Thematic syllabus of elementary school curriculum poetry class IV, one of the standards for reading competence is to understand the text by reading aloud, intensive reading, and reading fairy tales with the basic competence of reading text aloud (20-25 sentences) with the correct pronunciation and intonation. While in semester 2 there is also a reading competency standard that is understanding texts by intensive reading (150-200 words) and reading poetry with basic competencies in reading poetry with correct pronunciation, intonation, and expression. This shows that reading with pronunciations and intonations that are true and right in elementary school students in grade IV is one of the competencies or abilities that must be possessed.
Therefore, it is not impossible if the fourth grade elementary school students already have the ability to read poetry with pronunciation and intonation that is already very good. Moreover, the activity of reading aloud in class learning activities is often carried out, this will further train students' ability to recite every word they say when reading with the appropriate intonation.

The explanation above is in accordance with the opinion of (Puspitasari, 2013) states that "reading aloud is an activity carried out with loud and clear vocals. Loud here is not screaming, but louder the voice to help other people in understanding what we are reading. In addition, it must be expressed according to the contents of the text being read and in general, she emphasized that there are 4 important aspects to consider in reading aloud including word suppression, sentence or intonation songs, pauses, and mastery of punctuation.

\section{Conclusions}

Based on the presentation of data and the discussion as stated, the skills to read poetry of elementary school students in terms of the pronunciation aspect are very good. The acquisition of average score assessed by three assessors was 3.49 from the ideal value of 4.00. This means that the percentage of the ability to read poetry in terms of pronunciation is around $87.16 \%$. This is because, parents are often taught how to pronounce Indonesian, especially poetry at home by reading aloud. Thus, the pronunciation model of fourth grade students in reading poetry at SDN Bontokamase Gowa can be used as a model or basis in reading poetry for all elementary schools in Gowa District. 


\section{APPENDIX}

\begin{tabular}{|c|c|c|c|c|c|}
\hline \multicolumn{6}{|c|}{ Pronunciation aspect } \\
\hline \multirow{2}{*}{ Respondents } & \multicolumn{3}{|c|}{ Assessor } & \multirow{2}{*}{ Reason for indicators } & \multirow{2}{*}{ Category } \\
\hline & $\mathbf{I}$ & II & III & & \\
\hline $\mathrm{R} 1$ & 4 & 4 & 3 & $\begin{array}{l}\text { AI: accurate word and clear in reading title, lines and rhymes } \\
\text { A2: accurate word and clear in reading title, lines and rhymes } \\
\text { A3: accurate word and clear less in reading title, lines and rhymes }\end{array}$ & VERY GOOD \\
\hline $\mathrm{R} 2$ & 3 & 4 & 3 & $\begin{array}{l}\text { AI: accurate word and clear less in reading title, lines and rhymes } \\
\text { A2: accurate word and clear in reading title, lines and rhymes } \\
\text { A3: accurate word and clear less in reading title, lines and rhymes }\end{array}$ & GOOD \\
\hline $\mathrm{R} 3$ & 4 & 4 & 4 & $\begin{array}{l}\text { AI: accurate word and clear in reading title, lines and rhymes } \\
\text { A2: accurate word and clear in reading title, lines and rhymes } \\
\text { A3: accurate word and clear in reading title, lines and rhymes }\end{array}$ & VERY GOOD \\
\hline R4 & 3 & 4 & 4 & $\begin{array}{l}\text { AI: accurate word and clear less in reading title, lines and rhymes } \\
\text { A2: accurate word and clear in reading title, lines and rhymes } \\
\text { A3: accurate word and clear in reading title, lines and rhymes }\end{array}$ & VERY GOOD \\
\hline R5 & 4 & 4 & 2 & $\begin{array}{l}\text { AI: accurate word and clear in reading title, lines and rhymes } \\
\text { A2: accurate word and clear in reading title, lines and rhymes } \\
\text { A3: unclear in reading title, lines and rhymes }\end{array}$ & VERY GOOD \\
\hline R6 & 4 & 4 & 4 & $\begin{array}{l}\text { AI: accurate word and clear in reading title, lines and rhymes } \\
\text { A2: accurate word and clear in reading title, lines and rhymes } \\
\text { A3: accurate word and clear in reading title, lines and rhymes }\end{array}$ & VERY GOOD \\
\hline R7 & 4 & 4 & 4 & $\begin{array}{l}\text { AI: accurate word and clear in reading title, lines and rhymes } \\
\text { A2: accurate word and clear in reading title, lines and rhymes } \\
\text { A3: accurate word and clear in reading title, lines and rhymes }\end{array}$ & VERY GOOD \\
\hline $\mathrm{R} 8$ & 4 & 4 & 2 & $\begin{array}{l}\text { AI: accurate word and clear in reading title, lines and rhymes } \\
\text { A2: accurate word and clear in reading title, lines and rhymes } \\
\text { A3: unclear in reading title, lines and rhymes }\end{array}$ & VERY GOOD \\
\hline R9 & 3 & 4 & 2 & $\begin{array}{l}\text { AI: accurate word but unclear in reading title, lines and rhymes } \\
\text { A2: accurate word but unclear in reading title, lines and rhymes } \\
\text { A3: unclear in reading title, lines and rhymes }\end{array}$ & GOOD \\
\hline $\mathrm{R} 10$ & 4 & 4 & 2 & $\begin{array}{l}\text { AI: accurate word and clear in reading title, lines and rhymes } \\
\text { A2: accurate word and clear in reading title, lines and rhymes } \\
\text { A3: accurate word and clear in reading title, lines and rhymes }\end{array}$ & VERY GOOD \\
\hline R11 & 3 & 4 & 3 & $\begin{array}{l}\text { AI: accurate word but unclear in reading title, lines and rhymes } \\
\text { A2: accurate word and clear in reading title, lines and rhymes } \\
\text { A3: accurate word but unclear in reading title, lines and rhymes }\end{array}$ & VERY GOOD \\
\hline $\mathrm{R} 12$ & 3 & 3 & 3 & $\begin{array}{l}\text { AI: accurate word but unclear in reading title, lines and rhymes } \\
\text { A2: accurate word but unclear in reading title, lines and rhymes } \\
\text { A3: accurate word but unclear in reading title, lines and rhymes }\end{array}$ & GOOD \\
\hline $\mathrm{R} 13$ & 4 & 4 & 4 & $\begin{array}{l}\text { AI: accurate word and clear in reading title, lines and rhymes } \\
\text { A2: accurate word and clear in reading title, lines and rhymes } \\
\text { A3: accurate word and clear in reading title, lines and rhymes }\end{array}$ & VERY GOOD \\
\hline R14 & 4 & 3 & 4 & $\begin{array}{l}\text { AI: accurate word and clear in reading title, lines and rhymes } \\
\text { A2: accurate word but unclear in reading title, lines and rhymes } \\
\text { A3: accurate word and clear in reading title, lines and rhymes }\end{array}$ & VERY GOOD \\
\hline R15 & 3 & 3 & 4 & $\begin{array}{l}\text { AI: accurate word but unclear in reading title, lines and rhymes } \\
\text { A2: accurate word but unclear in reading title, lines and rhymes } \\
\text { A3: accurate word and clear in reading title, lines and rhymes }\end{array}$ & VERY GOOD \\
\hline R16 & 4 & 3 & 3 & $\begin{array}{l}\text { AI: accurate word and clear in reading title, lines and rhymes } \\
\text { A2: accurate word but unclear in reading title, lines and rhymes } \\
\text { A3: accurate word but unclear in reading title, lines and rhymes }\end{array}$ & VERY GOOD \\
\hline R17 & 4 & 4 & 4 & $\begin{array}{l}\text { AI: accurate word and clear in reading title, lines and rhymes } \\
\text { A2: accurate word and clear in reading title, lines and rhymes } \\
\text { A3: accurate word and clear in reading title, lines and rhymes }\end{array}$ & VERY GOOD \\
\hline $\mathrm{R} 18$ & 3 & 3 & 4 & $\begin{array}{l}\text { AI: accurate word but unclear in reading title, lines and rhymes } \\
\text { A2: accurate word but unclear in reading title, lines and rhymes } \\
\text { A3: accurate word and clear in reading title, lines and rhymes }\end{array}$ & VERY GOOD \\
\hline R19 & 3 & 2 & 3 & $\begin{array}{l}\text { AI: accurate word but unclear in reading title, lines and rhymes } \\
\text { A2: unclear in reading title, lines and rhymes } \\
\text { A3: accurate word but unclear in reading title, lines and rhymes }\end{array}$ & ADEQUATE \\
\hline $\mathrm{R} 20$ & 4 & 4 & 4 & $\begin{array}{l}\text { AI: accurate word and clear in reading title, lines and rhymes } \\
\text { A2: accurate word and clear in reading title, lines and rhymes } \\
\text { A3: accurate word and clear in reading title, lines and rhymes }\end{array}$ & VERY GOOD \\
\hline
\end{tabular}


Table Continued

\begin{tabular}{|c|c|c|c|c|c|}
\hline $\mathrm{R} 21$ & 3 & 3 & 3 & $\begin{array}{l}\text { AI: accurate word but unclear in reading title, lines and rhymes } \\
\text { A2: accurate word but unclear in reading title, lines and rhymes } \\
\text { A3: accurate word but unclear in reading title, lines and rhymes }\end{array}$ & GOOD \\
\hline $\mathrm{R} 22$ & 4 & 3 & 3 & $\begin{array}{l}\text { AI: accurate word and clear in reading title, lines and rhymes } \\
\text { A2: accurate word and clear in reading title, lines and rhymes } \\
\text { A3: accurate word and clear in reading title, lines and rhymes }\end{array}$ & VERY GOOD \\
\hline $\mathrm{R} 23$ & 3 & 2 & 3 & $\begin{array}{l}\text { AI: accurate word but unclear in reading title, lines and rhymes } \\
\text { A2: unclear in reading title, lines and rhymes } \\
\text { A3: accurate word but unclear in reading title, lines and rhymes }\end{array}$ & ADEQUATE \\
\hline $\mathrm{R} 24$ & 4 & 4 & 3 & $\begin{array}{l}\text { AI: accurate word and clear in reading title, lines and rhymes } \\
\text { A2: accurate word and clear in reading title, lines and rhymes } \\
\text { A3: accurate word but unclear in reading title, lines and rhymes }\end{array}$ & VERY GOOD \\
\hline $\mathrm{R} 25$ & 2 & 2 & 3 & $\begin{array}{l}\text { AI: unclear in reading title, lines and rhymes } \\
\text { A2: unclear in reading title, lines and rhymes } \\
\text { A3: accurate word but unclear in reading title, lines and rhymes }\end{array}$ & BAD \\
\hline $\mathrm{R} 26$ & 3 & 4 & 4 & $\begin{array}{l}\text { AI: accurate word but unclear in reading title, lines and rhymes } \\
\text { A2: accurate word and clear in reading title, lines and rhymes } \\
\text { A3: accurate word and clear in reading title, lines and rhymes }\end{array}$ & VERY GOOD \\
\hline $\mathrm{R} 27$ & 4 & 3 & 4 & $\begin{array}{l}\text { AI: accurate word and clear in reading title, lines and rhymes } \\
\text { A2: accurate word but unclear in reading title, lines and rhymes } \\
\text { A3: accurate word and clear in reading title, lines and rhymes }\end{array}$ & VERY GOOD \\
\hline $\mathrm{R} 28$ & 4 & 2 & 3 & $\begin{array}{l}\text { AI: accurate word and clear in reading title, lines and rhymes } \\
\text { A2: unclear in reading title, lines and rhymes } \\
\text { A3: accurate word but unclear in reading title, lines and rhymes }\end{array}$ & GOOD \\
\hline R29 & 4 & 4 & 4 & $\begin{array}{l}\text { AI: accurate word and clear in reading title, lines and rhymes } \\
\text { A2: accurate word and clear in reading title, lines and rhymes } \\
\text { A3: accurate word and clear in reading title, lines and rhymes }\end{array}$ & VERY GOOD \\
\hline $\mathrm{R} 30$ & 4 & 4 & 4 & $\begin{array}{l}\text { AI: accurate word and clear in reading title, lines and rhymes } \\
\text { A2: accurate word and clear in reading title, lines and rhymes } \\
\text { A3: accurate word and clear in reading title, lines and rhymes }\end{array}$ & VERY GOOD \\
\hline R31 & 3 & 4 & 3 & $\begin{array}{l}\text { AI: accurate word and clear in reading title, lines and rhymes } \\
\text { A2: accurate word and clear in reading title, lines and rhymes } \\
\text { A3: accurate word and clear in reading title, lines and rhymes }\end{array}$ & VERY GOOD \\
\hline $\mathrm{R} 32$ & 4 & 4 & 4 & $\begin{array}{l}\text { AI: accurate word and clear in reading title, lines and rhymes } \\
\text { A2: accurate word and clear in reading title, lines and rhymes } \\
\text { A3: accurate word and clear in reading title, lines and rhymes }\end{array}$ & VERY GOOD \\
\hline R33 & 4 & 3 & 4 & $\begin{array}{l}\text { AI: accurate word and clear in reading title, lines and rhymes } \\
\text { A2: accurate word but unclear in reading title, lines and rhymes } \\
\text { A3: accurate word and clear in reading title, lines and rhymes }\end{array}$ & VERY GOOD \\
\hline R34 & 4 & 3 & 4 & $\begin{array}{l}\text { AI: accurate word and clear in reading title, lines and rhymes } \\
\text { A2: accurate word but unclear in reading title, lines and rhymes } \\
\text { A3: accurate word and clear in reading title, lines and rhymes }\end{array}$ & VERY GOOD \\
\hline R35 & 4 & 3 & 4 & $\begin{array}{l}\text { AI: accurate word and clear in reading title, lines and rhymes } \\
\text { A2: accurate word but unclear in reading title, lines and rhymes } \\
\text { A3: accurate word and clear in reading title, lines and rhymes }\end{array}$ & VERY GOOD \\
\hline R36 & 3 & 3 & 3 & $\begin{array}{l}\text { AI: accurate word but unclear in reading title, lines and rhymes } \\
\text { A2: accurate word but unclear in reading title, lines and rhymes } \\
\text { A3: accurate word but unclear in reading title, lines and rhymes }\end{array}$ & GOOD \\
\hline R37 & 4 & 4 & 4 & $\begin{array}{l}\text { AI: accurate word and clear in reading title, lines and rhymes } \\
\text { A2: accurate word and clear in reading title, lines and rhymes } \\
\text { A3: accurate word and clear in reading title, lines and rhymes }\end{array}$ & VERY GOOD \\
\hline
\end{tabular}

\section{REFERENCES}

[1] Adler, Mortimer J., and Charles Van Doren, "How to read a book: The classic guide to intelligent reading," Simon and Schuster, 2014.

[2] Education, Ministry of National, "The School-Based Curriculum," Jakarta: MONE, 2006.
[3] Djumingin, Sulastriningsih and Mahampang, "Teaching Prose of Fiction and Drama," Makassar: State University of Makassar Publisher, 2007.

[4] ----------, "Strategies and Applications of Innovative Learning Models for Literature," Makassar: State University of Makassar Publisher, 2011.

[5] Doyin, Mukh, "The art of reading poetry: preparation, training, performance, and assessment," Semarang: Bandungan Institute, 2008.

[6] Doyin, Mukh, "Teaching Poetry Reading," Semarang: Bandungan Institute. 2010. 
[7] Istanti, Wati. "Application of Modeling to Improve the Ability to Read Poetry (Classroom Action Research in Class VII Students at SMP N 1 Mojolaban)," Doctoral dissertation, Surakarta: State University of Surakarta, 2009.

[8] Mulyana, Sendang, "Interpreting and Reading Poetry," Semarang: Bandungan Institute, 2008.

[9] Mulyana et al, "Literature Studio," Jakarta: Ministry of Education and Culture, 2008.

[10] Nurgiyantoro, Burhan, "Children's Literature: Introduction to Understanding the World of Children," Yogyakarta: Gadjah Mada University Press, 2018.

[11] Prasetyono, Sunar Dwi, "The Secret of Teaching Reading to Children in Early Age," Yogyakarta: Diva Press, 2008.

[12] Puspitasari, Yuli Astri, "Improving the Ability to Read Aloud of Second Grade Students at SDN 159 / II Datar based on the Application of Explicit Instruction Learning Model (Direct Teaching) and the use of Picture Story Book Media," Scientific Article. FKIP Jambi University, 2013.

[13] Rahim, Farida, "Teaching Reading in Elementary Schools," Jakarta: Bumi Aksara, 2009.
[14] Salad, Hamdy, "Discourse Guide \& Appreciation of Poetry Reading," Yogyakarta: Student Library, 2014.

[15] Santoso, Puji. "Indonesian Language Learning and Materials in Elementary School," Jakarta: Open University. 2009.

[16] Soedarso, "Fast and Effective Reading System," Jakarta: Gramedia Pustaka Utama, 1991.

[17] Somadayo, Samsu, "Strategies and Techniques of Reading Learning," Yogyakarta: Graha Ilmu, 2011.

[18] Sukmadinata, Nana Syaodih, "Educational Research Methods," Bandung: Youth. Rosadakarya, 2011.

[19] Tang, Muhammad Rapi, "Basic Mosaic of Literary Theory," Makassar: UNM Publishing Agency, 2008.

[20] Tarigan, Henri Guntur. Reading is a Language Skill. Bandung: Angkasa Bandung, 2008.

[21] Wei, Chan Sheung. Some Crucial Issues on The Translation Of Poetic Discourse From The Chinese To ENGLISH. Gema Online Journal Of Language Studies. Vol. 3, No.2. 2010 .

[22] Winarni, Retno. Children's Literature Studies. Yogyakarta: Graha Ilmu, 2014. 